\title{
Dampak Penerapan Program SLPTT terhadap Pendapatan Usahatani Padi di Kecamatan Telagasari Kabupaten Karawang
}

\author{
Fajar Firmana* dan Rita Nurmalina \\ Mahasiswa Pascasarjana Departemen Agribisnis, Fakultas Ekonomi dan Manajemen \\ Institut Pertanian Bogor \\ Jl. Raya Darmaga, Bogor, Jawa Barat, 16680 \\ *Alamat korespondensi: fajarfirmana@yahoo.com
}

\begin{abstract}
The Impact of the Program SLPTT on the Paddy Farm Business Income in Telagasari District, Karawang Regency
\end{abstract}

Over the past five years, rice consumption level of Indonesian population is still relatively high, at an average of $136.268 \mathrm{~kg}$ per capita per year. Although rice production in Indonesia has increased, government still imports to meet domestic demand. One of government's efforts to solve the problem is by implementing the Field School of Integrated Crop Management (SLPTT). The purposes of this research are to describe the activity of technology on rice farming, to evaluate the implementation of SLPTT and non-SLPTT program, and to analyze the income of rice farm business from SLPTT and non-SLPTT program in Kalibuaya Village. The study was conducted with direct observation and interview to the rice farmers in Kalibuaya Village as respondents selected by cluster sampling and purposive sampling method. The differences of the technology components used in the rice farming activities were detected between farmers of the SLPTT and non-SLPTT program. Rice farm business of the SLPTT program wass more efficient than non-SLPTT program with ratios of $\mathrm{R} / \mathrm{C}$ on total cost were 1.88 and 1.79 , respectively.

Keywords: Rice production, Rice farming activities, R/ C, SLPTT

\begin{abstract}
ABSTRAK
Selama lima tahun terakhir, tingkat konsumsi beras penduduk Indonesia masih tergolong tinggi yaitu rata-rata 136,268 kg per kapita per tahun. Meskipun saat ini produksi beras di Indonesia mengalami peningkatan, akan tetapi sampai saat ini pemerintah masih melakukan impor untuk memenuhi kebutuhan dalam negeri. Salah satu upaya pemerintah untuk mengatasi masalah ini yaitu dengan menerapkan program Sekolah Lapang Pengelolaan Tanaman Terpadu (SLPTT). Tujuan penelitian ini adalah mendeskripsikan keragaan teknologi usahatani, mengevaluasi penerapan komponen teknologi program SLPTT dan non program SLPTT, menganalisis pendapatan usahatani padi program SLPTT dan non program SLPTT. Penelitian dilakukan dengan observasi langsung dan wawancara kepada petani sebagai responden di Desa Kalibuaya melalui metode cluster sampling dan purposive sampling, Terdapat beberapa perbedaan penggunaan komponen teknologi antara petani program SLPTT dan non SLPTT ketika melakukan kegiatan usahatani padi. Usahatani padi program SLPTT lebih efisien dibandingkan dengan non program SLPTT dengan rasio $\mathrm{R} / \mathrm{C}$ atas biaya total masing-masing sebesar 1,88 and 1,79 .
\end{abstract}

Kata Kunci: Produksi padi, Activitas usahatani padi, R/C, SLPTT

\section{PENDAHULUAN}

Indonesia merupakan salah satu negara dengan jumlah penduduk yang besar karena pada tahun 2005-2010 laju pertumbuhan penduduk Indonesia sebesar 1,3\% (Badan Pusat Statistik, 2014). Hal ini menjadi perhatian utama bagi pemerintah karena dengan jumlah penduduk yang besar, maka 
akan memengaruhi ketersedian terhadap bahan pangan. Penduduk Indonesia memiliki tingkat konsumsi yang tinggi terhadap beras karena selama lima tahun terakhir rata-rata tingkat konsumsi beras sebesar 136,268 kg per kapita per tahun (Badan Pusat Statistik, 2014). Tingkat konsumsi beras Indonesia pada tahun 2013 termasuk tinggi yakni mencapai $139,15 \mathrm{~kg}$ per kapita per tahun. Hal ini berbeda apabila dibandingkan dengan tingkat ratarata konsumsi beras dunia yang hanya $60 \mathrm{~kg}$ per kapita per tahun (Rosalina, 2013). Berdasarkan amanah UU Pangan 18/2012, pemerintah dituntut untuk bisa meningkatkan produksi padi nasional guna memenuhi kebutuhan pangan dalam negeri.

Peningkatan produksi beras dapat dilakukan melalui upaya peningkatan produktivitas. Selama tahun 2009 hingga 2013 produktivitas padi yang ada di Indonesia cenderung mengalami peningkatan setiap tahunnya dengan laju $0,76 \%$ per tahun, begitu juga dengan luas areal panen dan produksi gabah kering giling (GKG) yang mengalami peningkatan masing-masing dengan laju pertumbuhan $1,80 \%$ dan $2,57 \%$ per tahun. Akan tetapi sampai saat ini, untuk bisa memenuhi kebutuhan beras dalam negeri pemerintah tetap melakukan kebijakan impor.

Volume impor beras Indonesia setiap tahun tinggi, sehingga dapat dikatakan sebagai negara net importir. Selama tahun 2008-2012, volume ekspor beras berfluktuasi dengan kecenderungan mengalami penurunan. Secara statistik terjadi penurunan volume ekspor rata-rata $18,87 \%$ per tahun. Sebaliknya, volume impor cenderung mengalami peningkatan, terutama pada tahun 2011 yakni mencapai sekitar 2,7 juta ton. Walaupun volume impor pada tahun 2012 terjadi penurunan, tetapi volume impor masih tinggi yakni sebesar 1,93 juta. Secara statistik, volume impor meningkat sangat cepat dengan rata-rata $61,85 \%$ per tahun selama tahun 2008-2012.

Pemerintah telah melakukan berbagai upaya dengan banyak mengeluarkan dana untuk investasi pada sektor pertanian agar kebutuhan pangan dapat terpenuhi sesuai dengan perkembangan penduduk. Pembangunan pertanian dapat dilaksanakan dangan jalan menyempurnakan pola usahatani yang sudah ada dengan dilandasi oleh penerapan teknologi pertanian dan rehabilitasi lahan guna memenuhi kebutuhan hidup keluarga petani (Luntungan, 2012). Sudah banyak program pertanian seperti bantuan maupun subsidi benih, pupuk, jalan pertanian, dan alat dan mesin pertanian (alsintan) untuk kelancaran usahatani padi. Namun, menurut Supriadi dkk. (2012), sejauh ini masih sedikit upaya yang diberikan untuk memperhatikan pendidikan petani seperti kegiatan belajar secara terstruktur, peningkatan pemahaman petani, inovasi, adopsi, serta pengambilan keputusan. Petani Indonesia ada saat ini umumnya masih kurang mampu dalam menganalisis situasi dan membuat inovasi baru. Hal ini membuat pemerintah berinisiatif melakukan upaya dan solusi alternatif salah satunya adalah memberikan program Sekolah Lapang Pengelolaan Tanaman Terpadu (SLPTT).

Berdasarkan penelitian (Rachman \& Saryoko 2008) salah satu upaya untuk mengatasi masalah produksi beras dapat ditempuh melalui pendekatan pengelolaan tanaman (padi) terpadu (PTT) yang merupakan bentuk sinergisme antar komponen intensifikasi budidaya padi termasuk efisiensi pemupukan. Program SLPTT menerapkan berbagai komponen teknologi usahatani melalui penggunaan input produksi yang efisien menurut spesifik lokasi sehingga mampu menghasilkan produktivitas tinggi untuk menunjang peningkatan produksi yang berkelanjutan (Badan Litbang Pertanian, 2007). Program SLPTT padi saat ini sudah diterapkan pada beberapa provinsi sentra produksi padi di Indonesia. Pemilihan program SLPTT pada suatu provinsi dengan pertimbangan bahwa provinsi tersebut memiliki daerah yang berpotensi baik dalam hal pengembangan usahatani padi. Jawa Barat merupakan salah satu provinsi yang menerapkan program SLPTT karena dinilai sebagai provinsi yang memiliki banyak daerah berpotensi untuk bisa meningkatkan produksi padi di tingkat nasional.

Jawa Barat merupakan salah satu sentra penghasil padi terbesar di Indonesia sehingga memiliki peran penting untuk memenuhi kebutuhan konsumsi beras nasional. Salah satu daerah di Jawa Barat yang merupakan daerah penghasil padi adalah Kabupaten Karawang. Dikatakan sebagai daerah penghasil padi karena pertanian di Kabupaten Karawang memiliki luas tanam, produksi, dan produktivitas padi yang termasuk baik dibandingkan beberapa daerah lainnya. Upaya peningkatan produksi tanaman padi masih terus menjadi prioritas utama pemerintah setiap tahunnya. Pemerintah telah melakukan berbagai program untuk bisa membantu petani dalam meningkatkan hasil produksi dengan harapan dapat memenuhi kebutuhan nasional. Kebijakan pemerintah daerah terhadap pertanian seharusnya menjadi hal utama yang perlu diperhatikan agar kebijakan dapat memberikan dampak yang baik bagi perkembangan produksi pertanian dan kesejahteraan petani. Basourun \& Fasakin (2012) mengungkapkan bahwa daerah yang memiliki sumberdaya alam sawah padi melimpah perlu dimanfaatkan dengan 
baik oleh masyarakat dan pemerintah daerah melalui kerangka pembangunan daerah agar dapat meningkatkan kesejahtaraan dan memenuhi kebutuhan pangan.

Pada umumnya sikap petani di Indonesia berbeda-beda terhadap beberapa program yang diberikan oleh pemerintah. Perbedaan sikap petani ini dipengaruhi oleh faktor lingkungan atau alam, masyarakat maupun penyuluh, serta modal. Tujuan diadakannya program SLPTT adalah selain untuk meningkatkan hasil produksi juga untuk meningkatkan hasil pendapatan petani. Hal ini juga serupa dengan yang diungkapkan oleh Prayoga (2010) bahwa penyuluhan yang diberikan kepada petani dapat menurunkan efisiensi teknis usahatani sehingga dapat berpengaruh terhadap produksi padi.

Salah satu wilayah yang menerapkan program SLPTT di Kabupaten Karawang adalah Desa Kalibuaya, Kecamatan Telagasari. Kecamatan Telagasari merupakan salah satu kecamatan yang memiliki luas lahan sawah terluas di Kabupaten Karawang. Selain itu, penerapan program SLPTT di Kecamatan Telagasari telah dilakukan sejak tahun 2009. Salah satu desa di Kecamatan Telagasari yang memiliki luas lahan terluas dan telah menerapkan program SLPTT adalah Desa Kalibuaya. Tujuan pada penelitian ini adalah untuk mendeskripsikan keragaan teknologi pada usahatani padi yang menerapkan program SLPTT dan non program SLPTT, mendeskripsikan keragaan teknologi pada usahatani padi yang menerapkan program SLPTT dan non program SLPTT, serta mendeskripsikan keragaan teknologi pada usahatani padi yang menerapkan program SLPTT dan non program SLPTT.

\section{BAHAN DAN METODE}

Penelitian dilaksanakan di Desa Kalibuaya, Kecamatan Telagasari, Kabupaten Karawang, Provinisi Jawa Barat. Pemilihan lokasi penelitian ini secara sengaja (purposive) dengan pertimbangan bahwa Desa Kalibuaya merupakan salah satu desa yang memiliki luas lahan terluas di Kecamatan Telagasari, sebagian besar masyarakatnya berprofesi sebagai petani padi, dan memiliki sebagian kelompok tani yang telah menerapkan program SLPTT. Waktu pengumpulan data dimulai dari bulan Januari hingga Februari 2015.

\section{Jenis dan Sumber Data}

Penelitian ini menggunakan data sekunder dan data primer. Data sekunder yang diperoleh dari berbagai bahan pustaka dan data dari berbagai lembaga pemerintahan yaitu BPS Indonesia, BPS Jawa Barat, Dinas Pertanian Tanaman Pangan Jawa Barat, Dinas Pertanian Kabupaten Karawang, serta Balai Penyuluh Pertanian, Perikanan, dan Kehutanan (BP3K) Kecamatan Telagasari. Data primer diperoleh melalui hasil wawancara langsung dengan pihak dinas pertanian, kepala Unit Pelaksana Teknis Daerah (UPTD) Telagasari, dan petani responden. Petani yang diwawancarai adalah petani yang merupakan peserta program SLPTT dan petani non SLPTT di Desa Kalibuaya.

\section{Metode Penentuan Responden}

Responden dalam penelitian ini adalah para petani padi yang tergabung dalam beberapa kelompok tani di Desa Kalibuaya. Cluster sampling digunakan untuk membagi petani padi di Desa Kalibuaya antara kelompok tani yang menerapkan program SLPTT dan non SLPTT. Selanjutnya responden penelitian ini dipilih secara purposive sampling yakni terdiri dari petani yang menerapkan program SLPTT sebanyak 30 orang dan petani yang tidak menerapkan program SLPTT sebanyak 30 orang sehingga total responden sebanyak 60 orang.

\section{Metode Pengolahan dan Analisis Data}

Penelitian ini melakukan pengolahan dan analisis data secara kualitatif dan kuantitatif. Analisis kualitatif dilakukan untuk mendeskripsikan gambaran umum lokasi penelitian, karakteristik petani responden, keragaan usahatani padi, serta penerapn komponen teknologi. Analisis kuantitatif dilakukan untuk melakukan perhitungan mengenai analisis biaya usahatani, penerimaan usahatani, pendapatan usahatani, dan $\mathrm{R} / \mathrm{C}$ yang didapatkan melalui pengolahan data primer. Pengolahan data primer menggunakan bantuan software microsoft excel, selanjutnya hasil dari pengolahan data tersebut disajikan dalam bentuk tabel sehingga dapat diinterpretasikan.

\section{Biaya Usahatani}

Analisis biaya usahatani digunakan untuk mengetahui berapa biaya-biaya yang dikeluarkan oleh petani dalam kegiatan usahatani yang dilakukan petani. Biaya usahatani terdiri dari dua jenis yakni biaya tunai dan biaya tidak tunai. Biaya pertanian merupakan salah satu hal yang harus diperhatikan terutama apabila petani ingin melakukan perubahan penerapan komponen teknologi baru dan ketika tejadi masalah kondisi perekonomian di daerah tersebut (Ohen \& Ajah 2015). 


\section{Analisis penerimaan usahatani}

Analisis penerimaan usahatani digunakan untuk mengetahui berapa besarnya penerimaan yang diperoleh oleh petani dalam kegiatan usahatani. Perhitungan matematis penerimaan usahatani (rupiah) menurut Soekartawi (1995) adalah perkalian antara produksi yang diperoleh dalam suatu usahatani $(\mathrm{kg})$ dengan harga jual produk per unit (rupiah/kg).

\section{Ilmu dan Pendapatan Usahatani}

Menurut Shinta (2011), ilmu usahatani adalah ilmu yang menyelidiki segala sesuatu yang berhubungan dengan kegiatan orang melakukan pertanian dan permasalahan yang ditinjau secara khusus dari kedudukan pengusahanya sendiri. Pendapatan usahatani adalah balas jasa yang didapatkan oleh petani atas penggunaan faktor produksi, seperti lahan, modal, serta tenaga kerja. Pendapatan usahatani terdiri dari pendapatan atas biaya tunai dan pendapatan atas biaya total. Pendapatan merupakan salah satu indikator untuk mengukur kesejahteraan seseorang atau masyarakat sehingga pendapatan masyarakat ini mencerminkan kemajuan ekonomi suatu masyarakat (Lumintang, 2013).

\section{Efisiensi Usahatani}

Efisiensi usahatani merupakan faktor penting dalam proses produksi. Suatu proses produksi pada usahatani dikatakan efisien jika dapat menghasilkan output yang lebih tinggi dengan penggunaan input yang sama atau lebih rendah untuk menghasilkan sejumlah output tertentu (Ratih \& Harmini, 2012). Menurut Hernanto (1996) dalam Timoniar (2013) terdapat beberapa perhitungan untuk mengukur efisiensi pendapatan usahtani yaitu: (1) penghasilan kerja usahatani per setara pria, (2) pendapatan per unit areal usahatani, dan (3) rasio imbangan penerimaan dan biaya ( $\mathrm{R} / \mathrm{C}$ Rasio). Pada penelitian ini, perhitungan yang digunakan untuk mengukur efisiensi pendapatan usahatani padi adalah rasio imbangan penerimaan dan biaya.

Analisis imbangan penerimaan dan biaya (analisis R/C) digunakan untuk dapat melihat berapa penerimaan yang diperoleh petani dari setiap rupiah yang telah dikeluarkan untuk usahataninya sebagai manfaat. Rumus $\mathrm{R} / \mathrm{C}$ rasio adalah pembagian antara penerimaan total (rupiah) dengan biaya (rupiah). Kriteria keputusan yang digunakan untuk melihat hasil analisis $\mathrm{R} / \mathrm{C}$ rasio tersebut adalah usahatani menguntungkan $(R / C>1)$, usahatani impas $(R / C=1)$, dan usahatani merugikan $(\mathrm{R} / \mathrm{C}<1)$.

\section{HASIL DAN PEMBAHASAN}

\section{Kegiatan Usahatani Padi Petani Program SLPTT dan Non SLPTT di Desa Kalibuaya}

Kegiatan usahatani padi merupakan keseluruhan aspek budidaya padi sawah yang dilakukan oleh petani program SLPTT dan non SLPTT di Desa Kalibuaya, Kecamatan Telagasari, dimulai dari kegiatan persiapan lahan hingga pada tahap pemasaran. Tahapan kegiatan budidaya padi pada dasarnya adalah persiapan lahan, persiapan benih dan persemaian, penanaman, penyiangan, pemupukan, penyemprotan, serta pemanenan. Walaupun secara umum sama, namun terdapat beberapa perbedaan penggunaan komponen teknologi dari tahapan budidaya antara petani program SLPTT dan non SLPTT di Desa Kalibuaya.

\section{a. Persiapan Lahan}

Tahapan ini terdiri dari beberapa kegiatan, yaitu pembersihan lahan, mengawurkan jerami, pergantian tanah, pembajakan sawah, nampingan dan meratakan tanah. Pembersihan lahan merupakan kegiatan untuk memudahkan pekerjaan pada saat pengolahan lahan dilakukan. Pada kegiatan ini tidak ada perbedaan diantara petani SLPTT dan non SLPTT, dimana kegiatan yang dilakukan adalah membersihkan gulma, rerumputan dan bebatuan yang ada pada lahan. Setelah lahan sawah bersih maka kegiatan selanjutnya adalah menyebarkan jerami yang berasal dari musim panen sebelumnya. Jerami yang disebar di lahan sawah kemudian didiamkan sampai membusuk. Manfaat dari jerami yang telah dibusukkan akan menjadi pupuk organik sehingga dapat meningkatkan kesuburan tanah.

Pergantian Tanah (pemopokan) dilakukan pada 14-18 hari setelah jerami disebar. Pembajakan sawah yang bertujuan untuk mempercepat proses pembusukan sisa tanam dilakukan dengan membalikan tanah. Secara umum petani SLPTT dan non SLPTT melakukan pembajakan sawah dengan menggunakan traktor yang dilakukan oleh pekerja. Nampingan adalah membersihkan pematang atau galengan sawah dengan menggunakan cangkul, pematang sawah dipapas dan menggantinya dengan tanah hasil pembajakan. Meratakan tanah adalah meratakan permukaan lahan sehingga air irigasi yang ada di petakan tersebar merata.

\section{b. Persemaian Benih}

Sebelum menyemai, petani harus menentukan varietas benih apa yang akan ditanam. 
Pemilihan varietas benih untuk petani program SLPTT adalah Mekongga, karena varietas tersebut yang dianjurkan oleh penyuluh kepada petani. Lain halnya dengan petani non SLPTT yang memilih banyak varietas seperti Mekongga, Ciherang, dan Inpari 14. Penentuan luas lahan semai dan jumlah benih disesuaikan dengan luas lahan sawah yang akan digarap oleh petani. Petani program SLPTT menyediakan lahan persemaian rata-rata seluas 150 $\mathrm{m}^{2}$ dan petani non SLPTT seluas $134 \mathrm{~m}^{2}$ untuk 1 hektar luas lahan yang akan ditanami. Jumlah bibit yang ditanam berdasarkan anjuran dari penyuluh, yaitu sebanyak 20-25 kg per hektar. Perbedaan benih Varietas Unggul Baru (VUB) yang dilakukan oleh petani SLPTT dan petani non SLPTT menyebabkan adanya perbedaan produktivitas karena pemilihan benih petani SLPTT disesuaikan dengan kondisi di lapangan sesuai dengan musim tanam. Pembentukan benih VUB dapat menghasilkan varietas dengan keunggulan yang beragam sesuai dengan spesifikasi lokasi dengan potensi agroekosistem, kendala, dan preferensi pengguna (Yuniarti, 2015). Penentuan umur bibit yang dianjurkan oleh penyuluh kepada petani program SLPTT adalah 10-20 hari setelah sebar benih. Beberapa petani Non SLPTT menggunakan bibit muda dengan umur kurang dari 10 hari atau bahkan lebih dari 20 hari. Waktu yang digunakan untuk penanaman ketika bibit yang disemai mencapai umur 15-21 hari. Tahapan terakhir pada kegiatan ini adalah pencabutan bibit.

\section{c. Penanaman}

Kegiatan penanaman diawali dengan membuat garis-garis tanam di lahan sawah untuk menentukan barisan dan jarak tanam. Anjuran penanaman di Desa Kalibuaya agar dilakukan secara serentak. Kegiatan penanaman dilakukan dengan bantuan para pekerja tanam. Pemberian upah disesuaikan dengan sistem tanam yang diterapkan oleh petani. Penanaman dengan legowo 2:1 atau legowo 4:1 dibayar sebesar Rp 900.000/ha, sedangkan untuk sistem tanam pada umumnya sebesar Rp 800.000/ha.

Sistem tanam yang dilakukan oleh petani di Desa Kalibuaya beraneka ragam karena memiliki kebiasaan dan persepsi masing-masing. Petani program SLPTT dianjurkan untuk melakukan sistem tanam jajar legowo 2:1. Fakta yang dijumpai pada penelitian ini hanya 13 orang $(43,33 \%)$ petani program SLPTT yang telah mengikuti anjuran tersebut, sedangkan untuk petani non SLPTT bahkan tidak ada satupun yang menerapkan aturan tanam jajar legowo 2:1. Umumnya sistem tanam yang banyak dilakukan oleh petani khususnya petani Non SLPTT yaitu sistem jajar legowo 8:1 dan tegel dengan ukuran $25 \mathrm{~cm}$ x $25 \mathrm{~cm}$ atau $30 \mathrm{~cm}$ x 30 $\mathrm{cm}$.

\section{d. Pemeliharaan}

Penyiangan adalah menghilangkan rumput penggangu yang tumbuh di sekitar tanaman padi serta di pinggir pematang sawah. Penyiangan umumnya dilakukan dua kali dalam satu musim tanam. Alat yang digunakan pada kegiatan ini adalah parang dan gasrok. Penggunaan gasrok diharapkan dapat membantu petani agar kegiatan penyiangan lebih cepat. Namun faktanya tidak banyak petani menggunakan gasrok karena petani lebih memilih penggunaan obat herbisida yang dinilai lebih baik dan mudah.

Kegiatan pemupukan yang dianjurkan oleh program SLPTT adalah sebanyak tiga kali yaitu pemupukan dasar, pemupukan susulan pertama (15 hari setelah tanam), serta pemupukan susulan kedua (30 HST). Dosis pupuk sesuai dengan rekomendasi analisis status hara tanah dengan memperhatikan Bagan Warna Daun (BWD) untuk menentukan waktu memupuk, Petani SLPTT dianjurkan untuk memberikan pupuk organik. Sebagian besar petani SLPTT telah mengikuti anjuran jumlah pemupukan, waktu pemupukam, serta meningkatkan pemakaian pupuk organik, meskipun komposisi dosis pemupukan yang digunakan belum tepat sesuai anjuran. Pengendalian hama dan penyakit yang merupakan anjuran dari program adalah menyemprotkan pestisida sesuai dengan kebutuhan. Pada musim tanam ini, umumnya petani merasakan banyaknya serangan hama dan penyakit sehingga penyemprotan dilakukan 7-8 kali. Petani SLPTT tidak hanya menggunakan obat yang bersifat kimiawi karena adanya anjuran bagi petani untuk menggunakan obat organik.

Pengairan lahan sawah di Desa Kalibuaya berasal dari sumber pengairan BTLS IV dan BTLS V. Petani SLPTT dan non SLPTT tidak mengalami kesulitan dalam memperoleh air untuk mengairi sawahnya. Komponen pengairan berselang tidak ditekankan oleh penyuluh kepada petani SLPTT di Desa Kalibuaya. Pengairan berselang bertujuan untuk meningkatkan efisiensi dan menekan keracunan seperti kandungan besi (Fe). Penelitian yang dilakukan oleh Azwir \& Ridwan (2009) membuktikan bahwa perbaikan teknologi budidaya dengan pengairan berselang mampu meningkatkan 
produktivitas padi dibandingkan dengan cara lainnya.

e. Pemanenan

Petani program SLPTT dan non SLPTT melakukan waktu panen saat padi berumur 95-115 HST. Pada saat tanaman padi selesai dipanen, gabah dirontokkan dengan menggunakan mesin perontok yang disewa oleh petani dengan harga $\mathrm{Rp}$ $170.000 /$ ton - Rp 180.000/ton GKP. Proses perontokan panen yang dilakukan oleh petani SLPTT tidak semua sesuai dengan anjuran program yang menyarankan untuk dirontokkan secara langsung, tetapi petani memilih untuk didiamkan terlebih dahulu. Pada proses perontokan, pengurangan kehilangan pasca panen dapat dilakukan jika menggunakan alat perontok padi yang tepat (Hasbi, 2012).

\section{Permasalahan Usahatani Padi Petani Program SLPTT dan Non SLPTT di Desa Kalibuaya}

Pemasalahan usahatani pada subsistem hulu adalah meningkatnya harga benih, pupuk, dan pekerja. Upah pekerja mengalami peningkatan sebesar Rp 100 000/ha. Pada subsistem on-farm, permasalahan petani adalah serangan hama seperti tikus, keong mas, burung, kupu-kupu, kepik, penggerek batang, serta wereng. Pada sub sistem offfarm, permasalahan yang pertama adalah posisi tawar petani masih lemah ketika berhadapan dengan pembeli. Permasalahan kedua adalah rendahnya kehadiran anggota kelompok tani pada waktu kegiatan pertemuan program. Permasalah ketiga adalah koperasi unit desa (KUD) dan koperasi kelompok tani (KKT) yang sudah tidak bergerak dalam menjalankan perannya untuk membantu perekonomian di Desa Kalibuaya,

\section{Penerapan Komponen Teknologi Program SLPTT di Desa Kalibuaya}

Di Desa Kalibuaya, pada tahun 2014 terdapat 16 kelompok tani dengan total luas lahan kelompok 488 ha. Jumlah kelompok tani yang mengikuti program SLPTT sebanyak lima kelompok tani, yakni sri tani, karyatani, mekar jaya, mekarsakti, dan lugina. Luas lahan sawah yang digunakan dalam program SLPTT di Desa Kalibuaya terdiri dari 187,5 ha. Lahan sawah milik ketua kelompok tani SLPTT dijadikan sebagai Laboratorium Lapangan (LL).

Tabel 1. Persentase penerapan teknologi PTT oleh petani padi program SLPTT dan non program SLPTT.

\begin{tabular}{lcc}
\hline \multicolumn{1}{c}{ Komponen Teknologi } & Petani SLPTT (\%) & Petani Non SLPTT (\%) \\
\hline \multicolumn{1}{c}{ Komponen Teknologi Dasar } & & \\
Benih Varietas Unggul Baru & 100,00 & 96,67 \\
Benih bermutu dan bersertifikat & 73,33 & 66,67 \\
Pupuk organik dan jerami & 53,33 & 44,67 \\
Pemupukan berdasarkan kebutuhan tanaman & 43,33 & 23,33 \\
dan unsur hara & & \\
Penyemprotan pestisida organik & 60,00 & 40,00 \\
\hline \multicolumn{1}{c}{ Komponen Teknologi Pilihan } & & \\
Penggunaan bibit muda & 86,67 & 83,33 \\
Tanam bibit 1-2 tangkal per lubang & 53,33 & 59,00 \\
Menerapkan jarak tanam jajar legowo 2 & 43,33 & 0,00 \\
Penyiangan gulma dengan landak/gasrok & 13,33 & 36,67 \\
Waktu panen & 80,00 & 63,33 \\
Gabah dirontok langsung & 33,33 & 26,67 \\
\hline
\end{tabular}

Penerapan komponen SLPTT terdiri dari teknologi dasar dan teknologi pilihan. Teknologi dasar terdiri dari VUB inbrida atau hibrida, benih bermutu dan berlabel biru, pemberian bahan organik (jerami atau kompos), pengaturan populasi tanaman secara optimum, pemupukan berdasarkan kebutuhan tanaman dan status hara tanah, serta pengendalian Organisme Pengganggu Tanaman (OPT) dengan pendekatan Pengendalian Hama
Terpadu (PHT). Komponen teknologi pilihan terdiri dari pengolahan tanah sesuai musim dan pola tanam, penggunaan bibit muda (< 21 hari), tanam bibit 1-3 per lubang, pengaturan tanam (jajar legowo 2:1 atau 4:1), pengairan secara efektif dan efisien, penyiangan dengan landak atau gasrok, serta panen tepat waktu dan gabah segera dirontok. Berikut ini Tabel 1 adalah persentase jumlah petani responden yang 
menerapkan ke-13 teknologi SPTT di Desa Kalibuaya.

\section{Penerapan Komponen Teknologi Dasar}

Berdasarkan pada Tabel 1 bahwa teknologi dengan persentase penerapan paling tinggi oleh petani adalah penggunaan benih padi VUB. Apabila dilihat dari komponen teknologi kualitas benih, sebanyak 22 orang $(73,33$ persen $)$ telah menggunakan benih berlabel dan petani non SLPTT sebanyak 20 petani (66,67 persen). Berdasarkan anjuran dari program SLPTT di Desa Kalibuaya diharapkan petani untuk tidak menggunakan benih dari hasil panen sebelumnya karena benih tersebut akan berbeda kualitas dengan benih baru yang berlabel biru. Tidak adanya insentif bagi petani yang menggunakan benih sertifikat mengakibatkan masih adanya petani yang lebih memilih menggunakan benih non sertifikat. Hal ini serupa dengan yang diungkapkan oleh Podesta \& Rachmina (2011) bahwa harga benih sertifikat harus diupayakan tidak terlalu mahal dengan harga benih non sertifikat.

Pemberian pupuk organik yang dianjurkan adalah sebanyak 2 ton/ha. Jerami yang telah dibusukkan akan menjadi pupuk organik sehingga dapat juga meningkatkan kesuburan tanah. Petani SLPTT yang telah menerapkan komponen ini sebanyak 16 orang $(53,33 \%)$, sedangkan petani non SLPTT sebanyak 14 orang $(46,67 \%)$. Petani dengan tingkat kesadaran yang rendah akan manfaat jerami untuk kesuburan lahan, melakukan pembakaran jerami, menggunakan jerami untuk pakan ternak, ataupun memberikan jerami kepada orang lain.

Komponen teknologi PTT berikutnya adalah pengaturan populasi tanam secara optimum. Apabila petani menerapkan jajar legowo 2:1, maka kriteria ukuran jarak tanamnya adalah $50 \mathrm{~cm}$ x 25 $\mathrm{cm} \times 12,5 \mathrm{~cm}, 50 \mathrm{~cm} \mathrm{x} 25 \mathrm{~cm} \times 15 \mathrm{~cm}$, atau $40 \mathrm{~cm} \mathrm{x}$ $25 \mathrm{~cm} \times 15 \mathrm{~cm}$. Penyuluh akan mengetahui berapa populasi tanam yang dihasilkan oleh petani ketika adanya pertemuan dua dan pertemuan tiga dengan melakukan pengamatan di lapangan. Anjuran pemupukan berdasarkan kebutuhan tanaman dan status hara program SLPTT adalah pemupukan sebanyak tiga kali serta pemberian pupuk dasar dan organik dengan waktu yang tepat. Petani yang melakukan pempupukan seperti pada anjuran sebanyak 13 orang $(43,33 \%)$ petani SLPTT dan 7 orang $(23,33 \%)$ petani non SLPTT. Kondisi lain yang tidak banyak dilakukan oleh petani di Desa Kalibuaya adalah penggunaan pupuk organik. Jumlah pupuk organik yang digunakan lebih sedikit dari anjuran yang diberikan $2000 \mathrm{~kg} / \mathrm{ha}$, yakni petani SLPTT sebanyak 700,10 kg/ha dan petani non SLPTT sebanyak 346,98 kg/ha.

Penggunaan pestisida organik oleh petani SLPTT sebanyak 18 orang (60,00\%), sedangkan petani non SLPTT hanya sebanyak 12 orang $(40,00 \%)$. Tingkat kesadaran petani program SLPTT menggunakan pestisida organik lebih baik dibandingkan dengan petani non SLPTT. Selain penggunaan pestisida organik, petani juga diberikan penekanan untuk melakukan penyemprotan sesuai dengan kebutuhan dan tepat sasaran. Berdasarkan persentase jumlah penyemprotan yang dilakukan petani non SLPTT beragam dimulai dari penyemprotan 0-2 kali hingga penyemprotan lebih dari 12 kali. Hal ini menunjukkan bahwa petani lebih memilih untuk mengatasi hama dengan cara cepat, bahkan ada beberapa petani yang melakukan penyemprotan setiap minggunya.

\section{Penerapan Komponen Teknologi Pilihan}

Pengolahan tanah sesuai musim merupakan anjuran yang diberikan kepada petani SLPTT agar dapat mengoptimumkan produktivitas tanaman padi. Misalnya pemilihan benih Mekongga yang disesuaikan pada musim kemarau. Pola tanam lainnya yang dianjurkan di Desa Kalibuaya yaitu dalam hal waktu tanam yang dilakukan oleh petani program SLPTT terutama dalam satu kelompok tani harus serempak. Pada umumnya petani program SLPTT dan non SLPTT melakukan waktu tanam yang serentak (10-18 hari) berdasarkan kesepakatan dari setiap anggota.

Penanaman bibit muda dan tunggal berdasarkan anjuran program SLPTT di Desa Kalibuaya adalah bibit padi berumur 10-21 hari setelah sebar (HSS). Petani yang melakukan anjuran benih pada program SLPTT yaitu sebanyak 26 orang $(86,67 \%)$ petani SLPTT, sedangkan petani non SLPTT sebanyak 25 orang (83,33\%). Tanam bibit sesuai dengan program SLPTT di Desa Kalibuaya yakni 1-2 bibit per lubang. Petani yang menerapkan tanam bibit 1-2 bibit per lubang yaitu sebanyak 16 orang $(53,33 \%)$ petani SLPTT, sedangkan petani non SLPTT sebanyak 18 orang. Petani berpendapat apabila satu lubang hanya ditanami bibit dengan jumlah sedikit, maka akan ada bibit yang habis dimakan oleh hama.

Komponen berikutnya adalah pengaturan tanam melalui metode jajar legowo 2:1. Banyak petani memilih untuk menerapkan aturan tanam lainnya, seperti tegel, legowo 4, legowo 8, serta legowo 10. Pengairan berselang adalah pengaturan kondisi lahan dalam kondisi kering dan tergenang secara bergantian. Komponen pengairan berselang 
tidak ditekankan oleh penyuluh kepada petani program SLPTT di Desa Kalibuaya. Menurut penyuluh Desa Kalibuaya, petani program SLPTT masih belum bisa menerapkan komponen pengairan berselang secara baik seperti kedalaman air, waktu pengairan, serta tahapan kegiatannya.

Petani yang menggunakan alat gasrok yaitu sebanyak 4 orang (13.33\%), sedangkan petani non SLPTT sebanyak 11 orang (36.67\%). Petani SLPTT dan non SLPTT lebih banyak memberikan pekerjaan kepada pekerja untuk melakukan penyiangan dengan tangan dan menggunakan herbisida.
Ketepatan waktu panen padi sangat menentukan kualitas butir padi. Menurut penyuluh di Desa Kalibuaya waktu panen untuk tanaman padi varietas Mekongga dan Ciherang adalah 105-110 HST. Komponen panen untuk program SLPTT selain panen tepat waktu adalah anjuran gabah untuk segera dirontok. Petani beranggapan gabah yang dibiarkan selama beberapa hari tidak akan banyak mengurangi kualitas gabah. Hal ini yang menyebabkan baik petani program SLPTT maupun petani non SLPTT lebih memilih untuk melakukan perontokan gabah pada hari berikutnya.

Tabel 2. Biaya tunai dan diperhitungkan usahatani padi petani program SLPTT dan non SLPTT di Desa Kalibuaya pada tahun 2014.

\begin{tabular}{|c|c|c|c|c|c|c|}
\hline \multirow{2}{*}{ Komponen } & \multicolumn{3}{|c|}{ Petani SLPTT } & \multicolumn{3}{|c|}{ Petani Non SLPTT } \\
\hline & Jumlah & Harga/satuan & Total biaya & Jumlah & Harga/satuan & Total biaya \\
\hline \multicolumn{7}{|l|}{ Biaya Tunai } \\
\hline Benih & 22,38 & $9.420,00$ & $210.810,56$ & 15,35 & $11.283,33$ & $173.243,38$ \\
\hline $\begin{array}{l}\text { Pupuk } \\
\text { anorganik }\end{array}$ & 700,10 & 518,33 & $362.885,69$ & 364,75 & 506,67 & $184.808,83$ \\
\hline Urea & 201,82 & $2.580,00$ & $520.690,91$ & 251,11 & $2.590,00$ & $650.386,95$ \\
\hline TSP & 116,26 & $2.233,33$ & $259.653,20$ & 121,19 & $2.180,00$ & $264.433,20$ \\
\hline NPK & 96,44 & $2.333,33$ & $225.019,36$ & 87,82 & $2.373,33$ & $208.433,20$ \\
\hline NPK Phonska & 210,95 & $2.194,00$ & $462.835,51$ & 151,77 & $2.458,00$ & $373.053,04$ \\
\hline Pupuk organik & 700,10 & 518,33 & $362.885,69$ & 364,75 & 506,67 & $184.808,83$ \\
\hline Obat cair & & & $340.913,94$ & & & $520.285,92$ \\
\hline Obat padat & & & $296.525,19$ & & & $159.332,28$ \\
\hline TKLK & & & $1.046 .376,26$ & & & $754.476,93$ \\
\hline Biaya tanam & & & $843.333,33$ & & & $818.333,33$ \\
\hline Biaya olah tanah & & & $606.666,67$ & & & $630.000,00$ \\
\hline Sewa traktor & & & $790.000,00$ & & & $796.666,67$ \\
\hline Sewa perontok & & & $1.190 .777,55$ & & & $1.079 .688,35$ \\
\hline Pajak lahan & & & $30.000,00$ & & & $32.666,67$ \\
\hline Sewa lahan & & & $60.931,90$ & & & $80.000,00$ \\
\hline Karung & & & $29.017,17$ & & & $44.227,05$ \\
\hline Bagi hasil & & & $5.315 .366,16$ & & & $5.068 .379,64$ \\
\hline Total Biaya & & & $12.128 .976,8$ & & & $11.465 .122,6$ \\
\hline \multicolumn{7}{|l|}{ Tunai } \\
\hline \multicolumn{7}{|l|}{ Biaya } \\
\hline \multicolumn{7}{|l|}{ Diperhitungkan } \\
\hline Benih & 2,00 & $8.100,00$ & $16.200,00$ & 3,52 & $8.166,67$ & $28.736,53$ \\
\hline Penyusutan alat & & & $44.336,68$ & & & $38.676,53$ \\
\hline TKDK & 5,53 & $112.000,00$ & $619.466,41$ & 6,17 & $112.000,00$ & $690.643,84$ \\
\hline Sewa lahan & & & $1.127 .455,19$ & & & $1.207 .987,18$ \\
\hline Total Biaya & & & $1.807 .458,29$ & & & $1.966 .044,61$ \\
\hline \multicolumn{7}{|l|}{ Diperhitungkan } \\
\hline Total Biaya & & & $13.936 .426,17$ & & & $13.431 .167,21$ \\
\hline
\end{tabular}

Struktur Biaya Usahatani Petani SLPTT dan Non SLPTT

Hal yang menyebabkan total biaya tunai petani program SLPTT lebih besar dibandingkan dengan petani non SLPTT adalah adanya beberapa anjuran komponen teknologi yang mengharuskan petani untuk mengeluarkan biaya lebih besar. Dari semua komponen biaya tunai yang ada pada 
usahatani padi, baik petani program SLPTT maupun petani non SLPPT, komponen input yang memiliki proprosi terbesar dalam biaya tunai adalah tenaga kerja yang terdiri dari TKLK, sewa traktor, sewa perontok, biaya tanam, dan biaya olahan tanah. Proporsi tenaga kerja petani program SLPTT dan non SLPTT masing-masing sebesar 36,91\% dan $35,58 \%$.

Tabel 2 adalah biaya usahatani padi yang dikeluarkan oleh petani pada musim tanam kering II tahun 2014. Komponen biaya yang memiliki proporsi terbesar terhadap biaya yang diperhitungkan untuk petani program SLPTT dan petani non SLPTT adalah biaya sewa lahan masingmasing persentase sebesar $62,38 \%$ dan $61,14 \%$ dari total biaya yang diperhitungkan. Total biaya yang diperhitungkan petani non SLPTT lebih besar dibandingkan dengan petani program SLPTT dengan selisih sebesar Rp 158.586,32. Hal ini karena perbedaan yang cukup besar pada komponen sewa lahan diantara keduanya, dimana petani non SLPTT lebih banyak status kepemilikan lahan sendiri. Total biaya tunai per hektar petani SLPTT sebesar $\mathrm{Rp}$ 12.128.976,8 dan petani non SLPTT sebesar Rp 11.465.122,6. Total biaya diperhitungkan petani SLPTT sebesar $\mathrm{Rp}$ 1.807.458,29 dan total biaya usahatani sebesar Rp 13.936.426,17. Total biaya diperhitungkan petani non SLPTT sebesar Rp
1.966.044,61 dan total biaya usahatani sebesar Rp $13.431 .167,21$.

\section{Penerimaan Usahatani Petani Progam SLPTT dan Non SLPTT}

Analisis penerimaan usahatani terdiri dari penerimaan tunai dan penerimaan diperhitungkan. Penerimaan petani dipengaruhi oleh hasil produksi. Petani akan menambah hasil produksi bila setiap tambahan produksi tersebut akan menaikkan jumlah penerimaan yang akan diperoleh. (Lestari et al., 2011). Tabel 3 adalah penerimaan usahatani petani progam SLPTT dan non SLPTT pada musim tanam kering II tahun 2014. Penerimaan tunai usahatani petani program SLPTT lebih tinggi dibandingkan dengan petani non SLPTT. Hal ini terjadi karena produktivitas/ha tanaman padi dan harga gabah/kg yang diterima petani program SLPTT yang lebih tinggi dibandingkan dengan petani non SLPTT. Produktivitas yang lebih tinggi akan berpengaruh terhadap jumlah produksi yang dihasilkan. Perbedaan harga gabah dikarenakan kualitas gabah yang dihasilkan, seperti bulir yang lebih berisi (bernas). Selain penerimaan tunai usahatani, terdapat hasil panen yang diperhitungkan. Jumlah gabah yang disimpan oleh petani non SLPTT lebih tinggi dibandingkan dengan petani program SLPTT masing-masing 304,68 kg dan 489,37 kg.

Tabel 3. Penerimaan usahatani padi petani program SLPTT dan non SLPTT pada tahun 2014.

\begin{tabular}{lcccccc}
\hline \multirow{2}{*}{ Komponen Penerimaan } & \multicolumn{3}{c}{ Petani SLPTT } & \multicolumn{3}{c}{ Petani Non SLPTT } \\
\cline { 2 - 7 } & $\begin{array}{c}\text { Volume } \\
(\mathrm{GKP} / \mathrm{ha})\end{array}$ & $\begin{array}{c}\text { Harga } \\
(\mathrm{Rp} / \mathrm{kg})\end{array}$ & $\begin{array}{c}\text { Nilai } \\
(\mathrm{Rp})\end{array}$ & $\begin{array}{c}\text { Volume } \\
(\mathrm{GKP} / \mathrm{ha})\end{array}$ & $\begin{array}{c}\text { Harga } \\
(\mathrm{Rp} / \mathrm{kg})\end{array}$ & $\begin{array}{c}\text { Nilai } \\
(\mathrm{Rp})\end{array}$ \\
\hline Penerimaan Tunai & $5.287,49$ & $4.673,33$ & $24.710 .214,60$ & $4.726,22$ & $4.601,67$ & $21.748 .510,65$ \\
Penerimaan Non Tunai & 304,68 & $4.673,33$ & $1.423 .891,49$ & 489,37 & $4.601,67$ & $2.251 .938,16$ \\
\hline Total Penerimaan & $5.592,18$ & & $26.134 .106,09$ & $5.215,60$ & & $24.000 .448,81$ \\
\hline
\end{tabular}

\section{Pendapatan Usahatani Petani Program SLPTT dan Non SLPTT}

Analisis pendapatan usahatani dibagi menjadi pendapatan atas biaya tunai dan pendapatan atas biaya total. Pendapatan atas biaya tunai dan biaya total musim tanam gadu II petani program SLPTT lebih besar dibandingkan dengan petani non SLPTT. Selisih pendapatan biaya tunai diantara petani program SLPTT dan non SLPTT sebesar Rp 1.469.812,00/musim tanam, sedangkan selisih pendapatan atas biaya total sebesar $\mathrm{Rp}$ 1.628.398,32/musim tanam. Selisih pendapatan yang tidak terlalu besar diantara keduanya disebabkan karena kurang optimalnya total penerimaan yang didapatkan dan lebih besarnya total biaya untuk petani program SLPTT. Penerapan komponenkomponen teknologi yang dianjurkan dalam program SLPTT merupakan satu kesatuan yang harus diterapkan oleh petani untuk memperoleh hasil yang optimal, apabila salah satu atau beberapa teknologi tidak diterapkan maka target program SLPTT yang diinginkan tidak akan tercapai. Berikut ini Tabel 4 adalah pendapatan usahatani petani program SLPTT dan non SLPTT pada musim tanam kering II tahun 2014. 
Tabel 4. Penerimaan, biaya, pendapatan, serta $\mathrm{R} / \mathrm{C}$ rasio usahatani petani program SLPTT dan non SLPTT per hektar per musim pada tahun 2014.

\begin{tabular}{lrr}
\hline \multicolumn{1}{c}{ Komponen } & Petani SLPTT & \multicolumn{1}{c}{ Petani Non SLPTT } \\
\hline Penerimaan Tunai & $24.710 .214,60$ & $21.748 .510,65$ \\
Penerimaan yang Diperhitungkan & $1.423 .891,50$ & $2.251 .938,165$ \\
Total Penerimaan & $26.134 .106,09$ & $24.000 .448,81$ \\
\hline Total Biaya Tunai & $12.128 .967,88$ & $11.465 .122,60$ \\
Total Biaya Diperhitungkan & $1.807 .458,29$ & $1.966 .044,61$ \\
Total Biaya & $13.936 .426,27$ & $13.431 .167,21$ \\
\hline Pendapatan atas Biaya Tunai & $14.005 .138,21$ & $12.535 .326,21$ \\
Pendapatan atas Biaya Total & $12.197 .679,92$ & $10.569 .281,60$ \\
\hline R/C atas Biaya Tunai & 2,15 & 2,09 \\
R/C atas Biaya Total & 1,88 & 1,79 \\
\hline
\end{tabular}

\section{Analisis R/C Rasio Petani Program SLPTT dan Petani Non SLPTT}

Nilai $\mathrm{R} / \mathrm{C}$ atas biaya tunai dan biaya total usahatani petani program SLPTT lebih besar dibandingkan dengan petani non SLPTT. Nilai R/C atas biaya tunai usahatani petani program SLPTT adalah sebesar 2,15, sedangkan usahatani petani non SLPTT adalah sebesar 2,09. Nilai $\mathrm{R} / \mathrm{C}$ rasio atas biaya tunai memiliki arti bahwa dari setiap Rp 1,00 biaya tunai yang dikeluarkan oleh petani akan menghasilkan penerimaan sebesar $\mathrm{Rp} 2,15$ untuk petani program SLPTT dan sebesar Rp 2,09 untuk petani non SLPTT.

Selanjutnya apabila dilihat dari biaya total yang merupakan penjumlahan dari biaya tunai dan biaya yang diperhitungkan, nilai $\mathrm{R} / \mathrm{C}$ rasio biaya total usahatani petani program SLPTT adalah sebesar 1,88 , sedangkan usahatani petani non SLPTT adalah sebesar 1,79 . Nilai $\mathrm{R} / \mathrm{C}$ rasio atas biaya total memiliki arti bahwa dari setiap $\mathrm{Rp}$ 1,00 biaya total yang dikeluarkan oleh petani akan menghasilkan penerimaan sebesar $\mathrm{Rp}$ 1,88 untuk petani program SLPTT dan sebesar Rp 1,79 untuk petani non SLPTT.

Berdasarkan hasil dari analisis $\mathrm{R} / \mathrm{C}$ rasio atas biaya tunai dan biaya total, dapat dikatakan secara absolut bahwa usahatani petani program SLPTT lebih menguntungkan dibandingkan dengan petani non SLPTT. Nilai R/C rasio atas biaya tunai dan biaya total petani program SLPTT dan non SLPTT yang lebih besar dari satu, dikatakan efisien karena setiap tambahan biaya yang dikeluarkan akan menghasilkan tambahan penerimaan yang lebih besar daripada tambahan biayanya.

\section{SIMPULAN}

Keragaan usahatani padi di Desa Kalibuaya meliputi penggunaan komponen input, kegiatan budidaya, dan hasil usahatani. Tahapan kegiatan budidaya padi yang dilakukan oleh petani program SLPTT dan non SLPTT secara umum tidak jauh berbeda. Walaupun secara umum sama, namun terdapat perbedaan penggunaan komponen teknologi karena petani program SLPTT melakukan kegiatan budidaya sesuai dengan anjuran program SLPTT. Pelaksanaan program SLPTT di Desa Kalibuaya telah berjalan dengan baik, namun belum optimal. Hal ini karena tingginya persentase petani program SLPTT yang tidak menerapkan komponen teknologi anjuran program SLPTT. Pada musim gadu II 2014 terdapat beberapa komponen yang tidak diterapkan seperti pengairan secara efektif dan efisien, penyiangan dengan landak atau gasrok, serta panen tepat waktu dan gabah segera dirontok. Selain itu, komponen pilihan yang tidak dilakukan secara maksimal adalah pengaturan tanam jajar legowo 2 .

Berdasarkan analisis pendapatan usahatani yang dilakukan, usahatani padi petani program SLPTT secara absolut lebih menguntungkan dibandingkan dengan petani non SLPTT baik dilihat dari nilai pendapatan atas biaya tunai maupun atas biaya total. Berdasarkan analis nilai $\mathrm{R} / \mathrm{C}$ rasio, usahatani padi petani program SLPTT lebih efisien dibandingkan dengan petani non SLPTT dilihat dari nilai $\mathrm{R} / \mathrm{C}$ rasio terhadap biaya tunai maupun biaya total. R/C atas biaya tunai petani program SLPTT sebesar 2,10, sedangkan petani non SLPTT sebesar 2,09 . $\mathrm{R} / \mathrm{C}$ atas biaya total petani program SLPTT sebesar 1,84 , sedangkan petani non SLPTT sebesar 1,78 . 


\section{DAFTAR PUSTAKA}

Azwir dan Ridwan. 2009. Increasing of lowland rice productivity through management practices imrovement on rice cultivation. Akta Agrosia. 12(2): 212-218.

Badan Pusat Statistik. 2014. Konsumsi Beras dan Jumlah Penduduk di Indonesia Tahun 20102013. Tersedia online pada http://www.bps.go.id. (diakses 10 Februari 2015).

Badan Penelitian dan Pengembangan Pertanian Departemen Pertanian. 2007. Pengelolaan Tanaman Terpadu (PTT) Padi Sawah Irigasi. Tersedia online pada http://www.litbang.pertanian.go.id. (diakses 8 Maret 2015).

Hasbi. 2012. The improvement of rice postharvest technology in sub-optimal land. Jurnal Lahan Suboptimal. 1(2): 186-196.

Lestari, DF Wahyu, N Naomi, and B Najib. 2011. Income analysis and break event point of cucumber farming in Bangunrejo Village Tenggarong Seberang Subdistrict Kutai Kartanegara Regency. Jurnal EPP. 8(2): 2832.

Lumintang, MF. 2013. Analisis Pendapatan Petani Padi Di Desa Teep Kecamatan Langowan Timur. Skripsi Fakultas Ekonomi dan Bisnis. Universitas Sam Ratulangi. Manado. (Tidak dipublikasikan).

Ohen, SB and EA Ajah. 2015. Cost and return analysis in small scale rice production in Cross River State, Nigeria. International Research Journal of Agricultural Science and Soil Science. 5(1): 22-27.

Podesta, R dan D Rachmina. 2011. Efisiensi teknis dan ekonomis usahatani padi pandan wangi (Kasus di Kecamatan Warung Kondang,
Kabupaten Cianjur). Jurnal Agribisnis. 1(1): 58-75.

Prayoga, A. 2010. Produktivitas dan efisiensi teknis usahatani padi organik lahan sawah. Jurnal Agro Ekonomi. 28(1): 1-16.

Rachman, B dan A Saryoko. 2008. Analisis titik impas dan laba usahatani melalui pendekatan pengelolaan tanaman terpadu di Kabupaten Lebak-Banten. Jurnal Pengkajian dan Pengembangan Teknologi Pertanian. 11(1): 54-60.

Ratih, F dan Harmini. 2012. Efisiensi teknis usahatani ubi jalar di Desa Cikarang Kabupaten Bogor Jawa Barat. Jurnal Agribisnis. 2(1): 17-32.

Rosalina. 2013. Konsumsi Beras Ditargetkan Turun Sebesar 1.5 Persen. Tersedia online pada http://m.tempo.co. (diakses 17 Februari 2015).

Shinta, A. 2011. Ilmu Usahatani. Universitas Brawijaya Press-UB Press. Malang.

Soekartawi. 1995. Analisis Usahatani. UI Press. Jakarta.

Supriadi, H, IW Rusastra dan Ashari. 2012. Analisis Kebijakan dan Program SL-PTT Menunjang Peningkatan Produksi Padi Nasional. Pusat Sosial Ekonomi dan Kebijakan Pertanian. Badan Penelitian dan Pengembangan Pertanian.

Timoniar, KA. 2013. Keragaan dan Pendapatan Usahatani Program SLPTT dan Non Program SLPTT di Desa Sukaratu, Kecamatan Gekbrong, Kabupaten Cianjur. Skripsi Fakultas Ekonomi dan Manajemen, Institut Pertanian Bogor. Bogor. (tidak dipublikasikan).

Yuniarti, S. 2015. The growth and yield response of new superior varieties of upland rice in Pandeglang District, Banten. Pros Sem Nas Masy Biodiv Indon. 1(4): 848-851. 